\title{
Callus Formation and Production of Secondary Metabolites by Seedling Explants of Chenopodium quinoa
}

\author{
Heba Shahin \\ Plant Biotechnology Department, Genetic Engineering and Biotechnology Research \\ Institute (GEBRI), Sadat City University, Sadat City, Egypt.
}

\begin{abstract}
$\mathbf{Q}^{\mathrm{s}}$ UINOA (Chenopodium quinoa Willd) which is considered a pseudocereal or pseudograin, has been originated from the Andean region in South America, and is belonging to family Amaranthaceae. The highest percentage germination of seeds was achieved in MS medium with full strength in the full strength MS medium $(100 \%)$. Best callus production from seedling explants was obtained on MS medium supplemented with $2 \mathrm{mg} / \mathrm{L} \mathrm{2,} \mathrm{4-D+0.05mg/L} \mathrm{Kin.}$ Callus was also obtained when MS medium was fortified with $1 \mathrm{mg} / \mathrm{L} \mathrm{NAA}+0.5 \mathrm{mg} / \mathrm{L} \mathrm{BA}$, $1 \mathrm{mg} / \mathrm{L} 2,4-\mathrm{D}+0.5 \mathrm{mg} / \mathrm{L}$ BA and $3 \mathrm{mg} / \mathrm{L}$ PCIB. However, the percent culture response on these concentrations was lower. The lowest total amount of callus was found to be on MS medium containing $1 \mathrm{mg} / \mathrm{L}$ PCIB. Callus of explants were grown on MS media with $2 \mathrm{mg} / \mathrm{L} 2,4-\mathrm{D}+0.05$ $\mathrm{mg} / \mathrm{L}$ Kin gave the significant highest value $(22 \mu \mathrm{g} / \mathrm{g}$ fresh wt) of tocopherols content, followed by seedling on half strength MS medium (15.6). While the lowest value (2.1) was observed with Callus obtained from seedling planted on MS medium contained $0.5 \mathrm{mg} \mathrm{L}^{-1} \mathrm{NAA}+0.05$ $\mathrm{mg} \mathrm{L} \mathrm{L}^{-1} \mathrm{BA}$.
\end{abstract}

Protein extraction and enzymatic assay protein extraction and measurement of tyrosine aminotransferase (TAT) activity were performed. Enzyme activity in leaves was twofold higher than that in seeds. In callus cultures, activity was about onefold lower than in leaf extracts.

Keywords: Chenopodium quinoa (L.), NAA, PCIB, Callus formation, 2, 4-D and tocopherols.

\section{Introduction}

Chenopodium quinoa is an herbaceous dicotyledonous crop belonging to the $\mathrm{C} 3$ group of plants. It is a member of the Amaranthaceae family and is called a pseudo-grain plant. Pseudocereals are plants that produce seeds and fruits that are similar to grains and used in virtually the same ways. High in protein, nutrients, and vitamins, pseudocereals are most commonly gluten free and considered whole grains, despite not being a true grain (Jacobsen et al., 2003). Quinoa appears as an important crop with the potential to contribute to food safety worldwide and is considered to be an optimal food source for astronauts.

Quinoa has recently become particularly popular because it is gluten-free. Moreover, it has a high nutritional value with an average of $14.8 \%$ protein and an exceptional balance of oil, protein and starch, (Wright et al., 2002 and Tang et al., 2015). Quinoa seedlings are a very nutritious being rich in amino acids (lysine), unsaturated fatty acids (linolenic acid, linoleic acid), minerals as co-factors in antioxidant enzymes (calcium, magnesium, iron, copper and zinc), tocopherols (vitamin E), saponins and phenolic compounds with antioxidant power (Rengasamy, 2006 and Vega-G'alvez et al., 2010). Moreover, quinoa exhibits not only an unusually high salt tolerance but it also can grow under extreme drought stress (Jacobsen et al., 2003). The main problems with quinoa culture is its susceptibility to many viral diseases which seeds of infected plants carry the virus transferred to next generation. One way to produce virus-free plants is the in vitro propagation. Low-frequency chimeric somatic embryos and a high number of regenerates with a limited level of somaclonal variation are more attractive than organogenesis as a plant regeneration system (Henry, 1998). The use of in vitro culture techniques for study and select of improved cell lines are also very useful tools because they offer a rapid selection on a mass scale. Plant cell, organ, and tissue culture have widely used as a tool for conventional crops production (Collonnier et al., 2001; Basu et al., 2002; Pauk et al., 2002; Borsani et al., 2003; Cherian \& Reddy, 2003; Zair et al., 2003 and Compton et al., 2004)

Corresponding author email: heba.shahin@gebri.usc.edu.eg

DOI: 10.21608/ejbo.2019.6323.1251

Edited by: Prof. Dr. Abdelfattah Badr, Faculty of Science, Helwan University, Cairo, Egypt.

(C)2019 National Information and Documentation Center (NIDOC) 
and halophytes (Cherian \& Reddy, 2002, 2003).

Tocopherols, collectively known as vitamin E, are lipophilic antioxidants, essential nutritional components for mammals and exclusively synthesized by photosynthetic organisms. Of the four forms ( $\alpha, \beta, \gamma$ and $\delta$ ), $\alpha$-tocopherol is the most important vitamin $\mathrm{E}$ form present in green plant tissues and has the highest vitamin E activity. Synthetic $\alpha$-tocopherol, which is a racemic mixture of eight different stereoisomers, is always less effective than $\alpha$-tocopherol the natural form ( $R$, $\mathrm{R}, \mathrm{R})$. This increases the interest in obtaining this molecule from natural sources, such as plant cell cultures (Caretto et al., 2010).

Tyrosine aminotransferase catalyses the reversible reaction of tyrosine + 2-oxoglutarate $\leftrightarrow$ 4-hydroxyphenylpyruvate + glutamate. In bacteria, tyrosine is produced from 4-hydroxyphenylpyruvate by TAT, but in plants it has been described that the enzyme works in the other direction (Buchanan et al., 2000), conversion of tyrosine to 4-hydroxyphenylpyruvate, which is the substrate for pathways producing plastoquinone, tocopherols, rosmaric acid and benzylisoquinoline alkaloids (Lee \& Facchini, 2011).

Here we examine a simple strategy for somatic embryogenesis using hypototyl and cotyledonal plants from Chenopodium seedlings that can contribute to further progress in this area.

\section{Materials and Methods}

Plant material, sterilization and preparation of explants

Seeds of quinoa (Chenopodium quinoa Willd.) were obtained from Agricultural Research Centre Giza, Egypt. The experimental design was in randomized complete block with four replications.

\section{Seeds sterilization and germination}

The seeds were carefully washed with detergent $(0.003 \%(\mathrm{w} / \mathrm{v})$ of Tween 20$)$ and rinsed with tap water for $10 \mathrm{~min}$. They were sterilized with sodium commercial hypochloride $60 \%$ for $20 \mathrm{~min}$. The seeds were carefully washed with 3 time's sterile distilled water for $15 \mathrm{~min}$.

Then, the sterilized seeds were plated on either full strength or half strength (Murashige \& Skoog, 1962) MS medium supplemented by $0.2 \mathrm{~g}$ gelrite and $30 \mathrm{~g}$ sucrose.
The cultures were kept in a growth chamber at $26 \pm 1^{\circ} \mathrm{C}$, and a photoperiod of $16 \mathrm{~h}$ lights $(30 \mu \mathrm{E}$. $\mathrm{m}^{-2} \mathrm{sec}^{-1}$, , Philips TL 33 light) and 8h dark.

\section{Callus induction}

The seeds were germinated within 10 days and these in vitro germinated seeds were used as a source of explants for further experiments. Explants with $0.5-1.0 \mathrm{~cm}$ length, from hypocotyl and $\left(0.5 \mathrm{~cm}^{2}\right)$ cotyledons of 10 days-old seedlings were cultured on a basal MS medium with different concentrations of plant growth regulators (Duchefa biochemistry, Netherlands) for callus induction (Table 1). All cultures were incubated at $25 \pm 2^{\circ} \mathrm{C}$ in the dark. To give a dark condition, impervious light plastic was used. After 4 weeks, calli were produced and transferred to light for 2 weeks and weighed.

TABLE 1. Different hormone treatments for callus establishment of Chenopodium quinoa used to test extracts for tocopherol content.

\begin{tabular}{ll}
\hline No & \multicolumn{1}{c}{ Medium Type } \\
\hline M1 & MS medium $+0.5 \mathrm{mg} \mathrm{L}^{-1} \mathrm{NAA}^{*+0}+05 \mathrm{mg} \mathrm{L}^{-1} \mathrm{BA}$ \\
M2 & MS medium $+1 \mathrm{mg} \mathrm{L}^{-1} \mathrm{NAA}^{*}$ \\
M3 & MS medium $+1 \mathrm{mg} \mathrm{L}^{-1} \mathrm{NAA}+0.5 \mathrm{mg} \mathrm{L}^{-1} \mathrm{KIN}^{* *}$ \\
M4 & MS medium $+1 \mathrm{mg} \mathrm{L}^{-1} \mathrm{NAA}+0.5 \mathrm{mg} \mathrm{L}^{-1} \mathrm{BA}^{* * *}$ \\
M5 & MS medium $+1 \mathrm{mg} \mathrm{L}^{-1} \mathrm{NAA}+0.05 \mathrm{mg} \mathrm{L}^{-1} \mathrm{BA}$ \\
M6 & MS medium $+2 \mathrm{mg} \mathrm{L}^{-1} 2,4-\mathrm{D}^{* * * *}+0.5 \mathrm{mg} \mathrm{L}^{-1}$ \\
M7 & MS medium $+2 \mathrm{mg} \mathrm{L}^{-1} 2,4-\mathrm{D}+0.05 \mathrm{mg} \mathrm{L}^{-1} \mathrm{KIN}$ \\
M8 & MS medium $+3 \mathrm{mg} \mathrm{L}^{-1} \mathrm{PCIB}^{* * * *}$ \\
M9 & Half MS \\
M10 & Full MS \\
M11 & seed \\
\hline
\end{tabular}

* Naphthalene acetic acid

** Kinetin

$* * *$ Benzyle adenine

$* * * * 2$, 4-Dichloroacetic acid

$* * * * *$ p-Chlorophenoxyisobutyric acid

\section{Extraction of tocopherols}

Extraction of tocopherols from seeds, leaves of seedling and callus cultures of $C$. quinoa (Table 1) was carried out taking care to protect the extracts from light and oxidizing conditions. A total of $5 \mathrm{~g}$ freeze-dried material or dry seeds were ground to a powder and stirred with $100 \mathrm{ml}$ methanol for $3 \mathrm{~h}$ in the dark at $25^{\circ} \mathrm{C}$, then sonicated in a Branson ultrasound bath for $40 \mathrm{~min}$. After filtration and centrifugation at $3000 \mathrm{~g}$ for $20 \mathrm{~min}$, the supernatant was dried in a rotary evaporator and weighed. The dried extract was resuspended in $100 \mathrm{ml} n$-hexane, 
sonicated again for $40 \mathrm{~min}$, and then centrifuged at $3000 \mathrm{~g}$ for $20 \mathrm{~min}$. The supernatant was dried and weighed and stored at $20^{\circ} \mathrm{C}$ until further use.

\section{HPLC analysis of tocopherols}

Extraction of tocopherols from seeds, leaves of seedling and callus cultures of $C$. quinoa (Table 1) was carried out in dark to protect the operations from light and oxidizing conditions. A total of $5 \mathrm{~g}$ freeze dried material or dry seeds were ground to a powder and stirred with $100 \mathrm{ml}$ methanol for $3 \mathrm{~h}$ in the dark at $25^{\circ} \mathrm{C}$, then sonicated in a Branson ultrasound bath for $40 \mathrm{~min}$. After filtration and centrifugation at $3000 \mathrm{~g}$ for $20 \mathrm{~min}$, the supernatant was dried in a rotary evaporator and weighed. The dried extract was resuspended in $100 \mathrm{ml} n$-hexane, sonicated again for $40 \mathrm{~min}$, and then centrifuged at $3000 \mathrm{~g}$ for $20 \mathrm{~min}$; the supernatant was dried and weighed, and stored at $20^{\circ} \mathrm{C}$ until further use.

\section{HPLC analysis of tocopherols}

Analyses were performed essentially as described by Bruni et al. (2004); accurately a proper quantity of investigation sample weighed into a $20 \mathrm{ml}$ glass stoppered-Erlenmeyer flask. $1 \mathrm{ml}$ of the solution composed of approximately $25 \mathrm{mg}$ of 2, 2, 5, 7, 8-pentametyl-6-hydroxychroman or 2-metyl-2-phytyl-6-hydroxychroman into a beaker and dissolved in $100 \mathrm{ml} \mathrm{n}$-hexane added to the flask using a whole pipette, and dilute with n-hexane to about $10 \mathrm{ml}$. Then, the solution was filtered through a membrane filter of a $0.45 \mu \mathrm{m}$ pore-size. the filtrate utilized as test solution for HPLC analysis.

\section{Protein extraction and TAT activity}

Protein extraction and enzymatic tests Protein extraction and measurement of tyrosine aminotransferase (TAT) activity were performed as described previously in Lopukhina et al. (2001). Total RNA from tha plant samples sprayed with $5 \mathrm{uM}$ coronatine and incubated for $2 \mathrm{~h}$ was extracted as described by Barkan (1989). Poly (A $\left.{ }^{+}\right)$RNA was isolated using Oligotex mRNA Kit (Oliagen, Hilden, Germany).

Enzyme activity was assayed using $100 \mu \mathrm{g}$ of total protein, as described by Lopukhina et al. (2001). Protein content was determined according to Lowry et al. (1951). Five g fresh plants were homogenized in 2 volumes of ice-cold buffer, containing $100 \mathrm{mM}$ potassium phosphate buffer (pH 7.5) and 0.1mM EDTA. The supernatant was made after filtration $0.1 \%(\mathrm{v} / \mathrm{v})$ with tergitol and an incubation period on ice followed for $15 \mathrm{~min}$.
The supernatant after centrifugation was utilized as crude enzyme extract.

The experiments were repeated twice, with three replicate measurements. Data were analyzed using the one-way ANOVA test with a significance threshold of $\mathrm{P} \leq 0.05$.

\section{Statistical analysis}

Thirty explants were cultured per treatment. Each treatment consisted of 40-50 polypropylene jars $(5 \mathrm{~cm}$ high) with 5 explants in each jar. In the table, we show percentages and means $\pm \mathrm{SE}$. The Student $t$-test and the $\chi 2$-test were used to evaluate the significance of differences with averages and percentages respectively. The tests were carried out at least twice and comparable results were achieved. The results were statistically analyzed by a factor analysis of variance, in fully randomized design according to the procedure at Snedecor \& Cochran (1981) and means were compared by multiple range tests.

\section{$\underline{\text { Results and Discussion }}$}

The first experiment was set up to find the most appropriate MS strength. The results showed that the interaction between MS strength and standard photoperiodicity had a significant effect on seed germination and that the highest percentage of germination $(100 \%)$ was achieved at full strength MS medium (Fig.1). By an increase of the concentration to full strength MS, the germination percentage was significantly increased. This is in agreement with Eisa et al. (2005) who have reported that acceptable seed germination of C. quinoa was observed in full strength of MS medium. The germination responses of halophytic seeds counting salinity, temperature, light and life form were determined by several factors (William et al., 1998)

The second experiment was set up to find out an appropriate combination of plant growth regulators for callus induction. Cotyledon segments gave the best callus initiation and, among the different media tested, maximum callus formation was achieved with $2.0 \mathrm{mg} \mathrm{L}^{-1} 2,4-\mathrm{D}$ and $0.05 \mathrm{mg} \mathrm{L}^{-1} \mathrm{KIN}$ (Table 2). Callus induction was also quite high with hypocotyl explants $(95 \%)$ at the same 2,4-D and KIN concentration. Eisa et al. (2005) reported that callus formation was achieved from hypocotyl segments of C. quinoa but not from root and cotyledon explants. In the current study, 
hypocotyls explants were used for callus formation. The results showed that maximum callus weight $(1.22 \mathrm{~g})$ and percent of callus induction (95\%) was obtained on MS medium supplement with $2.0 \mathrm{mg}$ $\mathrm{L}^{-1}$ 2,4-D and $0.05 \mathrm{mg} \mathrm{L}^{-1}$ KIN (Table 2 and Fig. 2 b). This is not in agreement with Eisa et al. (2005) who have reported that acceptable callus formation from hypocotyls explants of $C$. quinoa was observed in medium supplemented with 0.1 to $0.5 \mathrm{mg} \mathrm{L}^{-1} 2,4-\mathrm{D}$.

We also examined PCIB which is a genuine antiauxin. Interestingly, this compound resulted in lowest callus formation.

The use of plant growth regulators is of fundamental importance for controlling the organogenic response of each plant tissue/organ under in vitro conditions (Che et al., 2002 and Sugiyama \& Imamura, 2006). Studies have shown that 2,4-D is one of the most effective auxins for induction and growth of callus (Lee et al., 2004 and Burbulis et al., 2007). Hypocotyls of young seedlings are often used for in vitro regeneration of different plants (Campbell \& Durzan, 1975; Gamborg \& Shyluk, 1976; Gunay \& Rao, 1978; Kamat \& Rao, 1978; Fari \& Czako, 1981; Kameya \& Widholm, 1981 and Arrilaga et al., 1986). However, Al-Khayri et al. (1992) achieved callus formation from mature seed explant of Spinacia oleracea L. on medium supplemented with $0.75 \mathrm{mg} \mathrm{L}^{-1} 2,4-\mathrm{D}$ along with 2mg L $\mathrm{m}^{-1} \mathrm{KIN}$. Bhojwani \& Dantu (2013) reported that the texture and color of the callus are markers for regeneration. Callus size is also an important factor in survival of callus. Survival rates of small callus compared to large callus are less, which may be due to specific cell density (Hesami \& Daneshvar, 2016), so that they can independently continue to grow after separation from the explant.
So in this experiment, bulk of callus from MS medium supplement with $2 \mathrm{mg} \mathrm{L}^{-1} 2,4-\mathrm{D}$ along with $0.05 \mathrm{mg} \mathrm{L}^{-1} \mathrm{KIN}$.

\section{Tocopherols content}

Phenolics or polyphenols have received considerable attention because of their physiological characteristics, including antioxidant, antimutagenic and antitumour activities (Othman et al., 2007).

In $C$. quinoa cultures, the production of tocopherols was not influenced by the exogenous hormone supply, or by the presence/absence of chloroplasts

The total content of tocopherols ranged from 2.1 to $22 \mu \mathrm{g} \mathrm{g}^{-1} \mathrm{FW}$ (highest in M7) (Fig. 3 ) in different callus parts, seed and seedlings samples, which was similar to that in many fruits (1.1-84 $\left.\mu \mathrm{g} \mathrm{g}^{-1} \mathrm{FW}\right)$, vegetables (1.0-30 $\mu \mathrm{g} \mathrm{g}^{-1}$ FW), legumes (4.8-16.7 $\left.\mu \mathrm{g} \mathrm{g}^{-1} \mathrm{FW}\right)$ and cereals (17-60 $\left.\mu \mathrm{g} \mathrm{g}^{-1} \mathrm{FW}\right)$ reported earlier by Caretto et al. (2010). The most abundant tocopherol in $C$. quinoa leaves was $\alpha$-tocopherol followed by $\gamma$ - and $\delta$-tocopherol. $\alpha$-Tocopherol is reported to have greater vitamin E activity and occurs in leaf tissues of various plant species (Carvalho et al., 2013). The content of $\alpha$-tocopherol in C. quinoa leaves $\left(101.1 \mu \mathrm{g} \mathrm{g}^{-1} \mathrm{FW}\right)$ was higher than the value reported in Amaranthus caudatus $\left(11.3 \mu \mathrm{g} \mathrm{\textrm {g } ^ { - 1 }}\right.$ FW), Arabidopsis (10 $\left.\mu \mathrm{g} \mathrm{g}^{-1} \mathrm{FW}\right)$, Chenopodium quinoa $\left(1.98 \mu \mathrm{g} \mathrm{g}^{-1} \mathrm{FW}\right)$, sunflower $\left(14 \mu \mathrm{g} \mathrm{g}^{-1} \mathrm{FW}\right)$ and tobacco $\left(43 \mu \mathrm{g} \mathrm{g}^{-1} \mathrm{FW}\right)$ cell cultures (Gala et al., 2005; Antognoni et al., 2008 and Harish et al., 2013) while lower than the value reported in Carthamus tinctorius $\left(167.7 \mu \mathrm{g} \mathrm{g}^{-1} \mathrm{FW}\right)$ and Vitis vinifera $\left(261.5 \mu \mathrm{g} \mathrm{g}^{-1} \mathrm{FW}\right)$ cell cultures (Chavan et al., 2011 and Cetin, 2014).

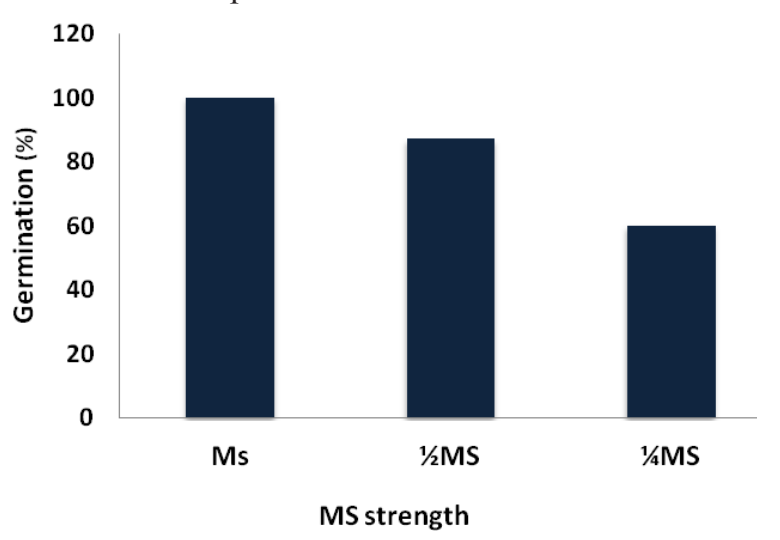

Fig. 1. Effect of different strength of MS medium on percentage $f$ seed germination of Chenopodium quinoa. 
TABLE 2. Effect of different concentrations of growth regulators on callus induction in hypocotyls and cotyledon explants of Chenopodium quinoa and different letters within columns indicate significant differences $(\mathbf{P}<\mathbf{0 . 0 5})$.

\begin{tabular}{lccc}
\hline & Callus formation (\%) & FW callus (g) & DWcallus (g) \\
\hline $1 \mathrm{mg} \mathrm{L}^{-1} \mathrm{NAA}$ & $53 \pm 3.7 \mathrm{~d}$ & $1.5 \pm 0.04 \mathrm{c}$ & $0.15 \pm 0.02 \mathrm{c}$ \\
$0.5 \mathrm{mg} \mathrm{L}^{-1} \mathrm{NAA}+0.05 \mathrm{mg} \mathrm{L}^{-1} \mathrm{BA}$ & $47 \pm 6.3 \mathrm{e}$ & $1.0 \pm 0.14 \mathrm{~d}$ & $0.1 \pm 0.042 \mathrm{~d}$ \\
$1 \mathrm{mg} \mathrm{L}^{-1} \mathrm{NAA}+0.5 \mathrm{mg} \mathrm{L}^{-1} \mathrm{~K}$ & $65 \pm 4.5 \mathrm{c}$ & $1.3 \pm 0.13 \mathrm{~d}$ & $0.15 \pm 0.056 \mathrm{~d}$ \\
$1 \mathrm{mg} \mathrm{L}^{-1} \mathrm{NAA}+0.5 \mathrm{mg} \mathrm{L}^{-1} \mathrm{BA}$ & $46 \pm 6.6 \mathrm{e}$ & $1.3 \pm 0.102 \mathrm{~d}$ & $0.13 \pm 0.12 \mathrm{~d}$ \\
$1 \mathrm{mg} \mathrm{L}^{-1} \mathrm{NAA}+0.05 \mathrm{mg} \mathrm{L}^{-1} \mathrm{BA}$ & $55 \pm 4.1 \mathrm{~d}$ & $1.6 \pm 0.021 \mathrm{c}$ & $0.16 \pm 0.04 \mathrm{c}$ \\
$3 \mathrm{mg} \mathrm{L}^{-1} \mathrm{NAA}$ & $67 \pm 6.5 \mathrm{c}$ & $2.3 \pm 0.09 \mathrm{~b}$ & $0.23 \pm 0.03 \mathrm{~b}$ \\
$1 \mathrm{mg} \mathrm{L}^{-1} 2,4 \mathrm{D}$ & $71 \pm 5.1 \mathrm{~b}$ & $2.4 \pm 0.044 \mathrm{~b}$ & $0.22 \pm 0.02 \mathrm{~b}$ \\
$2 \mathrm{mg} \mathrm{L}^{-1} 2,4 \mathrm{D}+0.05 \mathrm{mg}^{-1} \mathrm{KIN}$ & $95 \pm 3.1 \mathrm{a}$ & $3.6 \pm 0.18 \mathrm{a}$ & $0.36 \pm 0.12 \mathrm{a}$ \\
$1 \mathrm{mg} \mathrm{L}^{-1} 2,4 \mathrm{D}+0.5 \mathrm{mg} \mathrm{L}^{-1} \mathrm{BA}$ & $88 \pm 5.2 \mathrm{a}$ & $3.1 \pm 0.13 \mathrm{a}$ & $0,32 \pm 0.033 \mathrm{a}$ \\
$2 \mathrm{mg} \mathrm{L}^{-1} 2,4 \mathrm{D}+0.05 \mathrm{mg} \mathrm{L}^{-1} \mathrm{BA}$ & $77 \pm 6.3 \mathrm{~b}$ & $2.6 \pm 0.166 \mathrm{~b}$ & $0.25 \pm 0.056 \mathrm{~b}$ \\
$1 \mathrm{mg} \mathrm{L}^{-1} 2,4 \mathrm{D}+0.5 \mathrm{mg} \mathrm{L}^{-1} \mathrm{KIN}$ & $90 \pm 7.1 \mathrm{a}$ & $2.8 \pm 0.154 \mathrm{~b}$ & $0.29 \pm 0.012 \mathrm{~b}$ \\
$1 \mathrm{mg} \mathrm{L}^{-1} \mathrm{PCIB}$ & $69 \pm 7.5 \mathrm{c}$ & $2.0 \pm 0.132 \mathrm{~b}$ & $0.2 \pm 0.055 \mathrm{~b}$ \\
$3 \mathrm{mg} \mathrm{L}^{-1} \mathrm{PCIB}$ & $44 \pm 3.4 \mathrm{e}$ & $1.9 \pm 0.1 \mathrm{c}$ & $0.19 \pm 0.17 \mathrm{c}$ \\
\hline
\end{tabular}
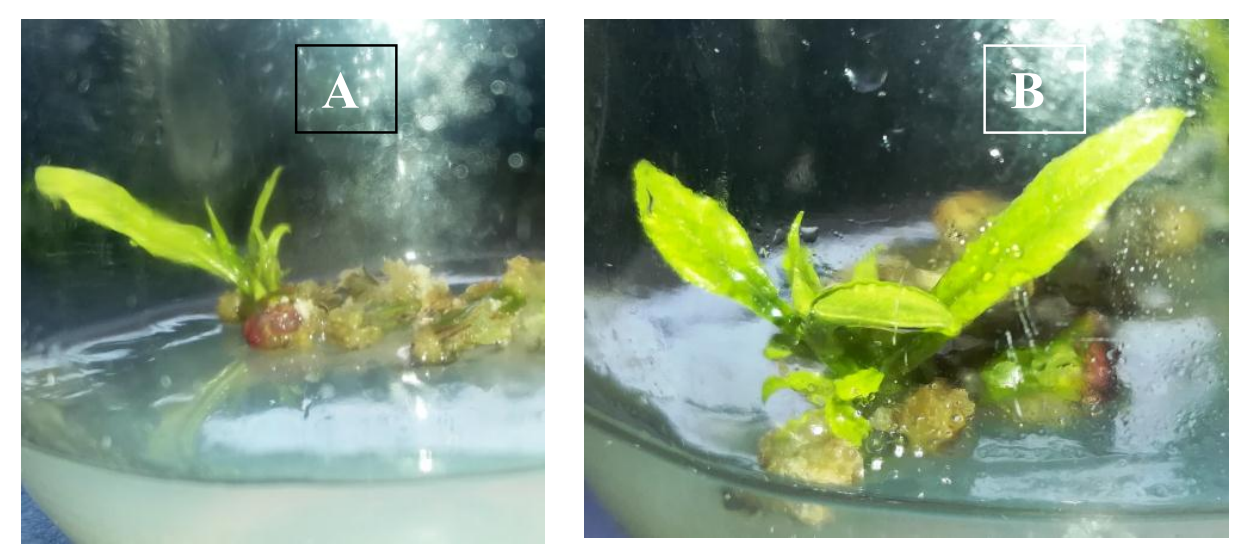

Fig. 2. Effect of different growth regulators with different concentrations on callus induction with indirect regeneration in hypocotyls explants of Chenopodium quinoa, (A) MS medium containing $1 \mathrm{mg} \mathrm{L}^{-1}$ NAA $+0.05 \mathrm{mg} \mathrm{L}^{-1} \mathrm{BA}$ and (B) MS medium containing $1 \mathrm{mg} \mathrm{L}^{-1} 2,4 \mathrm{D}+0.5 \mathrm{mg} \mathrm{L}^{-1} \mathrm{KIN}$.

An inverse relationship between growth rate and secondary metabolite production in plant cell and tissue cultures has often been reported (Hagendoorn et al., 1997 and Collin, 2001). On the other hand, they have a well-demonstrated antioxidant function and are known to increase in plants exposed to adverse environmental conditions that induce oxidative stress (Delong \& Steffen, 1997 and Havaux et al., 2005), thus behaving as secondary metabolites.

In callus cultures of $C$. quinoa, $\alpha$-tocopherol levels were about ten to 40 times lower than in leaves, irrespective of the culture medium used. This is in line with the general assumption that undifferentiated in vitro cultures, except for a few well-known exceptions (e.g., taxanes, Yukimune et al., 1996), often lose the capacity to produce the secondary metabolites normally synthesized in plant. In some cases, this is due to a lack of specialized cells or secretory structures (St-Pierre et al., 1999 and Pasqua et al., 2003). Indeed, the existence of a relationship between differentiation/ organization and secondary product formation in vitro has been well documented (Robins et al., 1991 and Biondi et al., 2002).

Tyrosine aminotransferase (TAT) activity in callus cultures

TAT activity was measured in protein extracts from seeds, leaves and callus cultures of $C$. quinoa. Enzyme activity in leaves was twofold higher than that in seeds (Fig. 4). In callus cultures, activity was about onefold lower than in leaf extracts, independent of the medium used. 


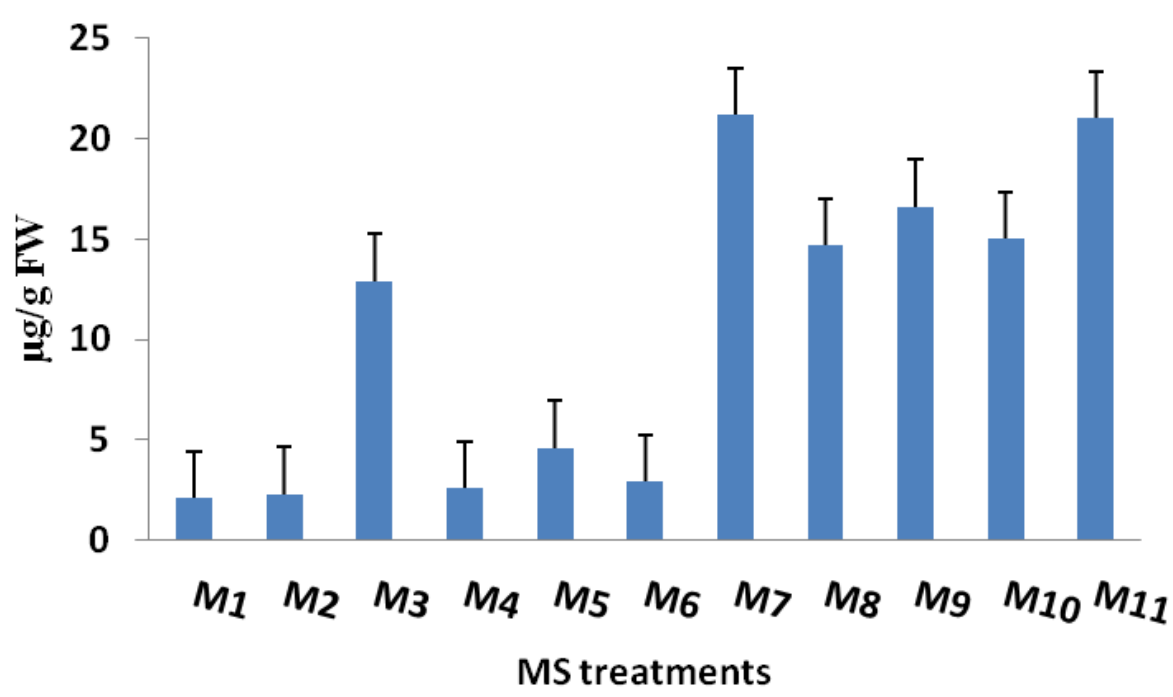

Fig. 3. Tocopherol levels in 7-week-old explants Influenced by various growth regulators added to MS medium on callus fresh weights obtained from in vitro hypocotyl of Chenopodium quinoa [Data \pm standard error].

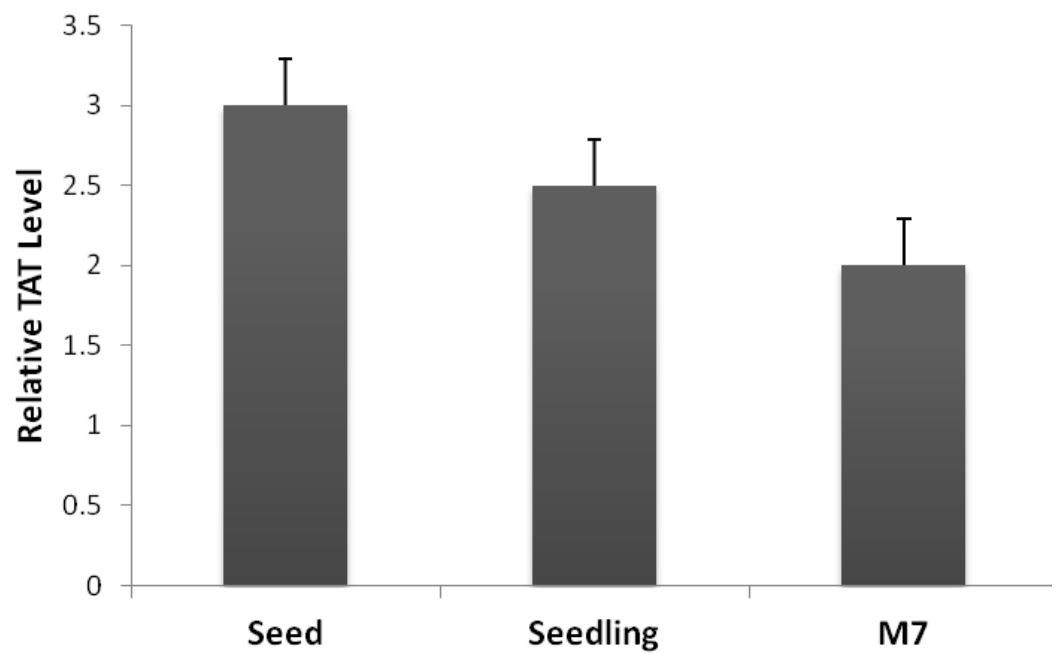

Fig. 4. Relative TAT level in different Chenopodium organs and callus at treatment $1 \mathrm{mg} \mathrm{L}^{-1} 2,4 \mathrm{D}+0.5 \mathrm{mg} \mathrm{L} \mathrm{L}^{-1} \mathrm{KIN}$ [Values represent means $\pm \mathrm{SE}$ of triplicate experiments].

Lopukhina et al. (2001) showed that the tyrosine aminotransferase annotated by locus tag At4g23600 from A. thaliana was regulated by coronatine. TAT was found to implicate in tocopherol anabolism in plants (Lopukhina et al 2001 and Hollander-Czytko et al., 2005). Additionally, the enzyme was also shown to be involved in the synthesis of rosmarinic acid in whole plants and in hairy root cell cultures (Xiao et al., 2009).

\section{Conclusion}

Conditions for initiation of callus in hypototyl and cotyledonal explants from Chenopodium seedlings were optimized in this study. Callogenesis showed range of responses depending on medium formulation, growth regulators combinations and concentrations. Various combinations and numerous medicinal properties of its extract and essential oils demand further and more studies about the other useful and unknown properties of this multipurpose plant.

\section{References}

Al-Khayri, J.M., Huang, F.H., Morelock, T.E. and Busharar, T.A. (1992) In vitro plant regeneration of spinach from mature seedderived callus. In vitro Cell. Dev. Biol. Plant, 28(2), 64-66.

Antognoni, M., Faudale, F., Poli, S. and Biondi, F. 
(2008) Methyl jasmonate differentially affects tocopherol content and tyrosine amino transferase activity in cultured cells of Amaranthus caudatus and Chenopodium quinoa. Plant Biol. 11, 161-169

Arrilaga, I., Brisa, M.C. and Segura, J. (1986) Somatic embryogenesis and plant regeneration from hypocotyl cultures of Digitalis obscura L. J. Plant Physiol. 124, 425-430.

Barkan, A. (1989) Tissue dependent plastid RNA splicing in maize: Transcripts from four plastid genes are predominantly unspliced in leaf meristems and roots. Plant Cell, 1, 437-445.

Basu, S., Gangopadhyay, G. and Mukherjee, B.B. (2002) Salt tolerance in rice in vitro: Implication of accumulation of $\mathrm{Na}, \mathrm{K}$ and proline. Plant Cell, Tissue Org. Cult. 69, 55-64.

Bhojwani, S.S. and Dantu, P.K. (2013) "Plant Tissue Culture: An Introductory Text", pp. 39-43. SpringerVerlag, Indian.

Biondi, S., Scaramagli, S., Oksman-Caldentey, K.-M. and Poli, F. (2002) Secondary metabolism in root and callus cultures of Hyoscyamus muticus L.: The relationship between morphological organisation and response to methyl jasmonate. Plant Sci. 163, 563-569.

Borsani, O., Valpuesta, M. and Botella, M.A. (2003) Developing salt tolerant plants in a new century: A molecular biology approach. Plant Cell, Tissue Org. Cult. 73, 101-115.

Bruni, R., Muzzoli, M., Ballero, M., Loi, M.C., Fantin, G., Poli, F. and Sacchetti, G. (2004|) Tocopherols, fatty acids and sterols in seeds of four Sardinian wild Euphorbia species. Fitoterapia, 75, 50-61.

Buchanan, B.B., Gruissem, W. and Jones, R.L. (2000) "Biochemistry \& Molecular Biology of Plants". John Wiley \& Sons.

Burbulis, N., Blinstrubiene, A., Sliesaravicius, A. and Kupriene, R. (2007) Some factors affecting callus induction in ovary culture of flax (Linum usitatissimum L.). Biologia, 53, 21-23.

Campbell, R.A. and Durzan, D.J. (1975) Induction of multiple buds and needles in tissue cultures of Picea glauca. Can. J. Bot. 53, 1652-1657.
Caretto, S., Nisi, R., Paradiso, A. and De Gara, L. (2010) Tocopherol production in plant cell cultures. Mol. Nutr. Food Res. 54, 726-730.

Carvalho, E., Fraser, P.D. and Martens, S. (2013) Carotenoids and tocopherols in yellow and red raspberries. Food Chem. 139, 744-752.

Cetin, E.S. (2014) Induction of secondary metabolite production by UV-C radiation in Vitis vinifera L. Öküzgözü callus cultures. Biol. Res. 47, 37.

Chavan, S.P., Nitnaware, K.M., Lokhande, V.H. and Nikam, T.D. (2011) Influence of growth regulators and elicitors on cell growth and $\alpha$-tocopherol and pigment productions in cell cultures of Carthamus tinctorius L. Appl. Microbiol. Biotechnol. 89, 1701-1707

Che, P., Gingerich, D.J., Lall, S. and Howell, S.H. (2002) Global and hormone induced gene expression changes during shoot development in Arabidopsis. Plant Cell Rep. 14, 2771-2785.

Cherian, S. and Reddy, M.P. (2002) Micropropagation of the halophyte Suaeda nudiflora Moq. through axillary bud culture. Ind. J. Plant Physiol. 71, 40-43.

Cherian, S. and Reddy, M.P. (2003)Evaluation of $\mathrm{NaCl}$ tolerance in the callus cultures of Suaeda nudiflora Moq. Biolgia Plant, 46, 193-198.

Collins, T., Stone, J.R. and Williams, A.J. (2001) All in the family: The BTB/POZ, KRAB, and SCAN domains. Mol. Cell Biol. 21, 3609-3615.

Collonnier, C., Fock, I., Kashyap, V., Rotino, G.L., Daunay, M.C., Lian, Y., Marriska, I.K., Rajam, M.V., Servaes, A., Ducreux, G. and Sihachakr, D. (2001) Applications of biotechnology in eggplant. Plant Cell, Tissue Org. Cult. 65, 91-107.

Compton, M., Gray, D.J. and Gaba, V.P. (2004) Use of tissue culture and biotechnology for the genetic improvement of watermelon. Plant Cell, Tissue Org. Cult. 77, 231-243.

DeLong, J. and Steffen, K. (1997) Photosynthetic function, lipid peroxidation and $\alpha$-tocopherol content in spinach leaves during exposure to UVB radiation. Can. J. Plant Sci. 77(3), 453-459.

Eisa, S., Koyro, H.W., Kogel, K.H. and Imani, J. (2005) Induction of somatic embryogenesis in cultured 
cells of Chenopodium quinoa". Plant Cell, Tissue Org. Cult. 81, 243-246.

Fari, M. and Czako, M. (1981) Relationship between position and morphogenetic response of pepper hypocotyl expiants cultured in vitro. Scientia Horticulture, 15, 207-213.

Gala, R., Mita, G. and Caretto, S. (2005) Improving $\alpha$-tocopherol production in plant cell cultures. $J$. Plant Physiol. 162, 782-784.

Gamborg, O.L. and Shyluk, J.P. (1976) Tissue culture, protoplasts, and morphogenesis in flax. Bot. Gaz. 4, 301-306.

Gunay, A.L. and Rao, P.S. (1978) In vitro plant regeneration from hypocotyl and cotyledon explants of red pepper (Capsicum). Plant Sci. Lett. 11, 365-372.

Hagendoorn, M.J.M., Jamar, D.C.L., Meykamp, B. and Vanderplas, L.H.W. (1997) Cell division versus secondary metabolite production in Morinda citrifolia cell suspensions. J. Plant Physiol. 150(3), 325-330.

Harish, M.C., Dachinamoorthy, P., Balamurugan, S. and Sathiskumar, R. (2013) Enhancement of $\alpha$-tocopherol content through transgenic and cell suspension culture systems in tobacco. Acta Physiol Plant, 35, 1121-1130.

Havaux, M., Eymery, F., Porfirova, S., Rey, P. and Dormann, P. (2005) Vitamin E protects against photoinhibition and photooxidative stress in Arabidopsis thaliana. Plant Cell, 17, 3451-3469.

Henry, R.J. (1998) Molecular and biochemical characterization of somaclonal variation. In: "Somaclonal Variation and Induced Mutation in Crop Improvement", Jain, S.M., Brar, D.S. and Ahloowalia, B.S. (Eds.), pp. 485-499. Kluwer Academic Publishers, Dordrecht.

Hesami, M. and Daneshvar, M.H. (2016) Development of a regeneration protocol through indirect organogenesis in Chenopodium quinoa Willd. Indo-Am. J. Agric. Vet. Sci. 4(1), 25-32.

Hollander-Czytko, H., Grabowski, J., Sandorf, I., Weckermann, K. and Weiler, E.W. (2005) Tocopherol content and activities of tyrosine amino transferase and cystine lyase in Arabidopsis under stress conditions. J. Plant Physiol. 162(7), 767-770.

Jacobsen, S.E., Mujica, A. and Jensen, C.R. (2003) The resistance of quinoa (Chenopodium quinoa Willd.) to adverse abiotic factors. Food Reviews International, 19, 99-109.

Kamat, M.G. and Rao, P.S. (1978) Vegetative multiplication of eggplants (Solanum melongena L.) using tissue culture techniques. Plant Sci. Lett. 13, 57-65.

Kameya, T. and Widholm, J. (1981) Regeneration from hypocotyl section of Glycine species. Plant Sci. Lett. 21, 289-294.

Lee, E.J. and Facchini, P.J. (2011) Tyrosine aminotransferase contributes to benzylisoquinoline alkaloid biosynthesis in Opium poppy. Plant Physiol. 157, 1067-1078.

Lee, E.J. and Facchini, P.J. (2011) Tyrosine aminotransferase contributes to benzylisoquinoline alkaloid biosynthesis in Opium poppy. Plant Physiol. 157, 1067-1078.

Lopukhina, A., Dettenberg, M., Weiler, E.W. and Hollander-Czytko, H. (2001) Cloning and characterization of a coronatine-regulated tyrosine aminotransferase from Arabidopsis. Plant Physiol. 126, 1678-1687.

Lowry, O.H., Rosebrough, N.J., Farr, A.L. and Randall, R.J. (1951) Protein measurement with the Folin phenol reagent. J. Biol. Chem. 193, 265.

Murashige, T. and Skoog, F. (1962) A revised medium for rapid growth and bio-assay with tobacco tissue cultures. Physiol. Plant, 15, 473-497.

Othman, A., Ismail, A., Ghani, N.A. and Adenan, I. (2007) Antioxidant capacity and phenolic content of Cocoa beans. Food Chemistry, 100, 1523-1530.

Pasqua, G., Monacelli, B., Silvestrini, A. (2003) Accumulation of essential oils in relation to root differentiation in Angelica archangelica L. Eur. J. Histochem. 47, 87-90.

Pauk, J., Ertugrul, F., Bartók, T., Mihály, R., Kiss, O., Cseuz, L., and Dudits, D. (2002) Improvement of wheat abiotic stress resistance via genetic transformation. Acta Biologica Szegediensis, 46(34), 5-7. 
Rengasamy, P. (2006) World salinization with emphasis on Australia. Journal of Experimental Botany, 57, 1017-23.

Robins,R.J., Parr, A.J. and Walton, N.J. (1991) Studies on the biosynthesis of tropane alkaloids in Datura stramonium L. transformed root cultures. 2. On the relative contribution of L-arginine and Lornithine to the formation of the tropane ring. Planta, 183, 196-201.

Snedecor, G.W. and Cochran, W.G. (1981) "Statistical Methods" $7^{\text {th }}$ ed. Iowa State Univ. Press, Ames, Iowa, USA.

St-Pierre, B., Vazquez-Flota, F.A. and De Luca, V. (1999) Multicellular compartmentation of Catharanthus roseus alkaloid biosynthesis predicts intercellular translocation of a pathway intermediate. Plant Cell, 11, 887-900

Sugiyama, M. and Imamura, K. (2006) Dose, time and tissue-dependent effects of 5-bromo-2deoxyuridine on the in vitro organogenesis of Arabidopsis thaliana. Plant Cell Tiss. Org. Cult. 87, 17-25.

Tang, Y., Li, X., Zhang, B., Chen, P.X., Liu, R. and Tsao, R. (2015) Characterisation of phenolics, betanins and antioxidant activities in seeds of three Chenopodium quinoa Willd. genotypes. Food Chem. 166, 380-388.

William, J., Ungar, I.A. and Mitchell, P. (1998) Effect of salinity on germination and seedling growth of two Atriplex species (Chenopodiaceae). Annals of Botany, 82, 167-175.

Wright, K.H., Pike, O.A., Fairbanks, D.J. and Huber, C.S. (2002) Composition of Atriplex hortensis, sweet and bitter Chenopodium quinoa seeds. $J$. Food Sci. 67, 1383-1385.

Vega-G'alvez, A., Miranda, M., Vergara, J., Uribe, E., Puente, L. and Mart'inez, E.A. (2010) Nutrition facts and functional potential of quinoa (Chenopodium quinoa Willd.). An ancient Andean grain: A review. Journal of the Science of Food and Agriculture, 90, p. 2541-2547.

Xiao, Y., Di, P., Chen, J., Liu, Y., Wansheng Chen, W. and Zhanget, L. (2009) Characterization and expression profiling of 4-hydroxyphenylpyruvate dioxygenase gene (Smhppd) from Salvia miltiorrhiza hairy root cultures. Mol. Biol. Rep. 36, 2019-2029.

Yukimune, Y., Tabata, H., Higashi, Y. and Hara, Y. (1996) Methyl jasmonate induced over production of paclitaxel and baccatin III in Taxus cell suspension cultures. Nature Biotech. 14, 1129-113.

Zair, I., Chlyah, A., Sabounji, K., Tittahsen, M. and Chlyah, H. (2003) Salt tolerance improvement in some wheat cultivars after application of in vitro selection pressure. Plant Cell Tissue and Organ Culture, 73, 237-244.

(Received 22/11/2018; accepted 27/2/2019) 


\section{دراسة تكوين الكالس وانتاج المركبات الثانوية من البادرات لنبات الكينوى \\ هبة شاهين \\ قسم بيوتكنولوجيا النبات ـ معهد بحوث الهندسة الوراثية والتكنولوجيا الحيوية ـ جامعة السادات ـ مدينة \\ السادات - مصر.}

تعتبر الكينوا (Chenopodium quinoa Willd) من البذور الكاذبة، وقد نشأ من منطقة الأنديز في أمريكا

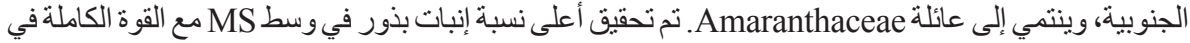
المنوسط MS الكامل (100\%). تم الحصول على أفضل إنتاج الكالس من مستخلصات الثتلات على وسط الكيط ال مدعوم بـ 4-D + 0.05 mg/1Kin ‘mg/122، تم الحصول على الكالس أيضا عندما تم تحصين MS /

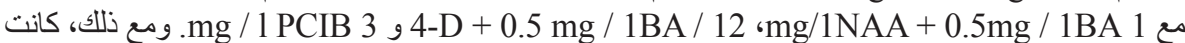
استجابة الثقافة المئوية على هذه التركيز ات أقل. تم العثور على أقل كمية إجمالية من الكالس على /

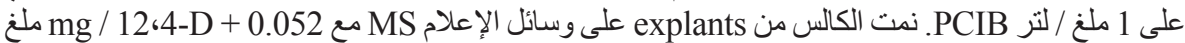

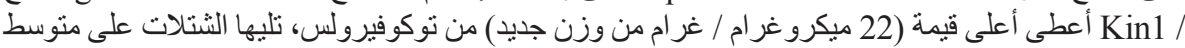

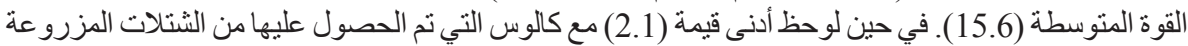

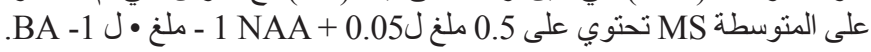

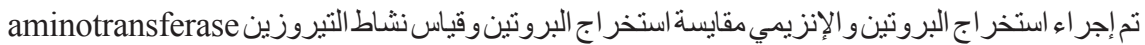
(TAT)

عنيف أقل من مستخلصات الأور اق. 